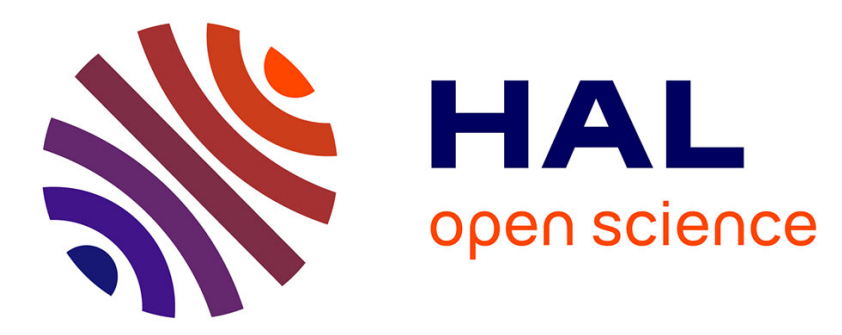

\title{
Relationship between anthropogenic sewage discharge, marsh structure and bird assemblages in a SW Atlantic saltmarsh
}

D.A. Cardoni, J.P. Isacch, M.E. Fanjul, M. Escapa, O.O. Iribarne

\section{To cite this version:}

D.A. Cardoni, J.P. Isacch, M.E. Fanjul, M. Escapa, O.O. Iribarne. Relationship between anthropogenic sewage discharge, marsh structure and bird assemblages in a SW Atlantic saltmarsh. Marine Environmental Research, 2011, 71 (2), pp.122. 10.1016/j.marenvres.2010.12.003 . hal-00664016

\author{
HAL Id: hal-00664016 \\ https://hal.science/hal-00664016
}

Submitted on 28 Jan 2012

HAL is a multi-disciplinary open access archive for the deposit and dissemination of scientific research documents, whether they are published or not. The documents may come from teaching and research institutions in France or abroad, or from public or private research centers.
L'archive ouverte pluridisciplinaire $\mathbf{H A L}$, est destinée au dépôt et à la diffusion de documents scientifiques de niveau recherche, publiés ou non, émanant des établissements d'enseignement et de recherche français ou étrangers, des laboratoires publics ou privés. 


\section{Accepted Manuscript}

Title: Relationship between anthropogenic sewage discharge, marsh structure and bird assemblages in a SW Atlantic saltmarsh

Authors: D.A. Cardoni, J.P. Isacch, M.E. Fanjul, M. Escapa, O.O. Iribarne

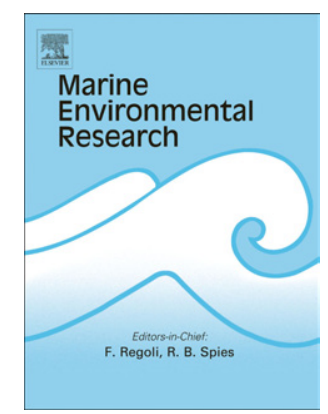

PII:

S0141-1136(10)00178-9

DOI:

10.1016/j.marenvres.2010.12.003

Reference: MERE 3491

To appear in: Marine Environmental Research

Received Date: 10 June 2010

Revised Date: 6 December 2010

Accepted Date: 7 December 2010

Please cite this article as: Cardoni, D.A., Isacch, J.P., Fanjul, M.E., Escapa, M., Iribarne, O.O.

Relationship between anthropogenic sewage discharge, marsh structure and bird assemblages in a SW

Atlantic saltmarsh, Marine Environmental Research (2010), doi: 10.1016/j.marenvres.2010.12.003

This is a PDF file of an unedited manuscript that has been accepted for publication. As a service to our customers we are providing this early version of the manuscript. The manuscript will undergo copyediting, typesetting, and review of the resulting proof before it is published in its final form. Please note that during the production process errors may be discovered which could affect the content, and all legal disclaimers that apply to the journal pertain. 


\section{ACCEPTED MANUSCRIPT}

1 Relationship between anthropogenic sewage discharge, marsh structure and bird assemblages in a SW Atlantic saltmarsh

3

6 Consejo Nacional de Investigaciones Científicas y Técnicas (CONICET) and

7 Departamento de Biología, Facultad de Ciencias Exactas y Naturales, Universidad

8 Nacional de Mar del Plata. Argentina, Funes 3250, (7600) Mar del Plata, Argentina.

$12{ }^{*}$ Corresponding autor: Universidad Nacional de Mar del Plata. Argentina, Funes 3250,

13 (7600) Mar del Plata, Argentina. Tel./Fax: 54 223/ 4753150; e-mail:

14 acardoni@mdp.edu.ar 
15 Abstract. One of the main effects of urbanization on coastal areas is through the

16 discharge of sewage, which increases nutrient concentrations in the receiving

17 environment. Salt marshes, like other coastal marine environments, are limited by

18 nutrients, mainly nitrogen, and thus increasing nutrient loadings to a marsh may have

19 consequences on marsh characteristics. We evaluated how the effects of nutrient

20 enrichment in the form of sewage input, affected the vegetation structure and bird

21 assemblages in a Spartina alterniflora salt marsh system near Bahía Blanca, Argentina

$22\left(39^{\circ} 01^{\prime} \mathrm{S}-56^{\circ} 25^{\prime} \mathrm{W}\right)$. Surveys of nutrient concentration, vegetation and birds were

23 made at three different distances from the sewage discharge source. The concentration

24 of ammonium, phosphate, and nitrate and the percent organic matter were higher in

25 marshes nearest to the sewage discharge source. Bird composition and abundance, and

26 vegetation physiognomy changed along a gradient of nutrient concentration. The

27 increased habitat complexity found near the areas of higher nutrient concentration was

28 exploited by birds that use neighboring interior and coastal habitats, including Spartina

29 densiflora marshes, freshwater marshes and upland shrubby habitats. Our results show

30 that local increases of nutrient inputs directly changed the vegetation physiognomy, and

31 indirectly the composition and abundance of bird assemblages.

33 Keywords: Saltmarsh bird, Spartina alterniflora, eutrophication, coast, Bahía Blanca

34 estuary, Argentina 
1. Introduction

The human population tends to live near the coastline (Wolanski, 2007), and thus, human activities can have greater impacts on the coastal ecosystems than on inland habitats (UNEP, 2006; Valiela, 2006). One of the main results of coastal populations is the discharge of sewage, which involves increased nutrient concentrations in the coastal environment (GESAMP, 1990). Salt marshes, like other coastal ecosystems, have relatively low-nutrient supplies (Valiela and Teal, 1974), and so nutrient increases can have large consequences i.e., changing the (1) structural complexity of marsh plants by enhancing biomass and stem density, (2) species composition, and (3) zonation patterns (Levine et al., 1998; Daleo et al., 2008). Also, nutrient increases may lead to marsh subsidence and habitat fragmentation, depending on the balance between sediment depositions, increased plant production, and increased decomposition (Valiela and Teal, 1974; Harper, 1995; Deegan, 2002). Specifically, in salt marshes characterized by large monospecific plant stands, nutrient enrichment may modify the plant physical structure by changing the plant growth form (Deegan, 2002). Nitrogen is usually the limiting nutrient controlling aboveground salt marsh vegetation production (Mendelssohn, 1979) and its availability increases the plant canopy and standing stocks, which is followed by higher rates of vegetation decay (Mitsch and Gosselink, 2000), and changes in species composition (Craft et al., 1995; Vaithiyanathan and Richardson, 1997). A case largely studied in the northern hemisphere is the change of the dwarf form of Spartina alterniflora into the tall form as a result of an increase in nutrients loading to a marsh (Valiela and Teal, 1974; Valiela et al., 1978). This increased nitrogen loading, however may or may not lead to a net gain of the marsh depending on the balance between the change in marsh plant production and decomposition. Increases in the primary 
60 2002) which is important in food webs (Deegan et al., 2000) and in creating peat that

61 forms the physical structure of the marsh platform (Friedrichs and Perry, 2001). Dead vegetation deposition ('wracks') on coastal marshes is a natural disturbance that can increase habitat heterogeneity (Valiela and Rietsma, 1995; Minchinton, 2002). Thus when nutrients loadings to a salt marshes increase we expect greater vegetation heterogeneity because of the increased canopy structure and more frequent occurrence of wracks.

Vegetation structure, composition, and floristic characteristics are substantial factors influencing bird habitat selection, because these factors provide food, nesting sites, and cover from predators (Macnally, 1990; Vickery et al., 2001; Buchanan et al., 2006).

Individuals select habitats that are an optimal combination of resources that allows them to perform multiple activities (e.g., foraging, breeding, roosting; Hilden, 1965; Fretwell and Lucas, 1970; Block and Brennan, 1993; Steele, 1993). Thus habitat structural heterogeneity is often a good predictor of bird diversity (Mac Arthur and Mac Arthur, 1961; Wiens, 1973; Roth, 1976). This result is probably due to the role of habitat complexity in promoting niche diversification (Wilson, 1974; Roth, 1976). There are many examples of the effect of nutrient enrichment on the aquatic environment (i.e., lakes estuaries; Robledano et al., 2008), such as those generated by algal blooms on waterbirds (Rosa et al., 2003), waterbird breeding (Rönkä et al., 2005) and shorebirds (Raffatelli 1999; Lopes et al., 2006). Bird abundance is positively correlated with lake 80 nutrient levels (Nilsson and Nilsson, 1978; Hoyer and Canfield, 1990, 1994; McCarty, 81 1997). However, although the effects of eutrophication are a well studied phenomena worldwide (Vitousek et al., 1997; Valiela, 2006), we are not aware of studies on the effects of nutrient enrichment on bird assemblages associated with salt marsh habitats. 
84 The salt marshes of the SW Atlantic are being modified at an increasing rate (Costa

et al., 2009), primarily by cattle grazing, fire (Isacch et al., 2004), and sewage

discharges (Nebia and Zalba, 2007; Martinetto et al., 2010). As happens elsewhere, in this region there are sewage discharges into the salt marshes. Specifically, there is an important sewage discharge on a Spartina alterniflora salt marsh in Bahía Blanca (Argentina) where salt marshes develop characteristics of those of the SW Atlantic (Isacch et al., 2006). Because increased nutrients on a salt marsh are expected to increase vegetation structure from the direct consequences of eutrophication (Daleo et al., 2008), we predicted that bird assemblage will also change from the indirect influences. Thus, we studied how nutrients change along a gradient from the sewage discharge source, and how this gradient is related with the vegetation structure and bird composition and abundance.

\section{Materials and Methods}

\subsection{Study area}

The study was performed at the Bahía Blanca estuary $\left(39^{\circ} 01^{\prime} \mathrm{S}-56^{\circ} 25^{\prime} \mathrm{W}\right.$;

Argentina), which includes one of the largest SW Atlantic salt marshes (Isacch et al., 2006; Fig. 1). The bay has a total area of $2300 \mathrm{~km}^{2}$ (Montesarchio and Lizasoain, 1981), with $10 \%$ of that surface covered by salt marshes and $20 \%$ by mudflats (Isacch et al., 2006). The salt marsh vegetation is dominated by two species; Spartina alterniflora grows in the lower marsh, and Sarcocornia perennis grows in the upper marsh. The industrial and port city of Bahía Blanca (300,000 inhabitants) is located on this coast. This city discharges its sewage into the bay relatively far from the city (Fig. 1). As in most of the bay, a large salt marsh dominated by S. alterniflora develops around the discharge point. Our observations suggested that there are strong variations in the salt 
109 marsh vegetation characteristics linked with the sewage discharge, and that they are not

110 typical of a natural gradient. The latter conclusion is supported by a study about

111 biomass variation of S. alterniflora marshes developed in that region (Isacch et al.,

112 2007), in which it was found that S. alterniflora plants reached larger sizes near the

113 sewage discharge.

114 Three sites were selected at different distances from the sewage to study the

115 relationship between anthropogenic nutrient concentration, the vegetation and birds,

116 (Fig. 1). The salt marsh growing around the sewage discharge pipe and the proximal

117 part of the discharge focus, were considered as the area of maximum nutrient effect

118 (Naposta marsh, 10 ha; Fig 1). A second site located approximately $200 \mathrm{~m}$ from that

119 source was considered as an area of medium effect (Midway marsh, 11.5 ha; Fig. 1). A

120 third site located at $10000 \mathrm{~m}$ from the main discharge source was considered as an area

121 of low effect (Maldonado marsh, 14.5 ha; Fig 1). All marshes have similar tidal

122 conditions, given that they are positioned to the SW, and were located at the same

123 distance $(\sim 1500 \mathrm{~m})$ from the main tidal channel. We assumed, therefore, that the three

124 marshes are similar except for their exposure to the sewage outfall.

\subsection{Nutrient levels}

127 To evaluate if the sewage discharge caused nutrient enrichment of the soil, we

128 collected sediment samples to determine the total organic matter content (OM),

129 concentration of dissolved inorganic nitrogen (nitrate and ammonium), and

130 concentration of inorganic phosphorous (i.e., phosphate) in porewater. Twenty sediment

131 samples were obtained using a stratified random sampling design at different distances

132 from the sewage channel: $20 \mathrm{~m}$ and $80 \mathrm{~m}$ (Naposta marsh), 150 and $220 \mathrm{~m}$ (Midway

133 marsh), and 10,000 m (Maldonado marsh). Sediment samples were collected by pushing 
134 a PVC core ( $3 \mathrm{~cm}$ diameter, $8 \mathrm{~cm}$ length) into the sediment. Cores were immediately

135 transported to the laboratory, where porewater was obtained by centrifugation $(9000 \times$

$136 \mathrm{~g}, 10 \mathrm{~min}$ ), filtered, and stored at $-20^{\circ} \mathrm{C}$ until the analysis of dissolved nutrients. The

137 nitrate concentration in porewater was determinated calorimetrically as nitrite after

138 reduction by cadmium followed by diazotization (Strickland and Parsons, 1968). The

139 concentration of ammonium was measured using the blue indophenol method

140 (Solórzano, 1969). The concentration of dissolved phosphate was measured using the

141 molybdate method (Strickland and Parsons, 1968). A set of samples were dried (7 days

142 at $\left.60{ }^{\circ} \mathrm{C}\right)$ and combusted $\left(8 \mathrm{~h}\right.$ at $\left.500{ }^{\circ} \mathrm{C}\right)$ to determine the total organic matter content

$143(\%)$ as the loss weight between dry and combusted sediment. The null hypothesis of no

144 difference in nutrients (nitrate, ammonium and phosphate concentrations, and organic

145 matter content) at different distances of the sewage discharge source were evaluated by

146 using a one-way ANOVA. An a posteriori LSD Fischer test was used to identify

147 differences when necessary (Zar, 1999). The relationship between nutrients

148 concentrations and distance to the sewage discharge source was assessed by simple

149 regression analysis (Zar, 1999).

150

\subsection{Vegetation and bird surveys}

We sampled vegetation and birds along 7 randomly distributed 100 x 60 m transects

153 in each marsh using the fixed-width strip-transect method (following Bibby et al.,

154 1997). Transects were separated by a minimum distance of $100 \mathrm{~m}$. Birds were surveyed

155 monthly between July 2007 and June 2008. The habitats included within transects were

156 the vegetated marsh platform and the open gaps (determined by dead vegetation

157 deposition, i.e. wracks). The vegetation physiognomy was surveyed in each bird

158 sampling unit (i.e., transect) during winter and summer. In each transect used to survey 
159 birds, we measured the following vegetation variables: height of the dominant strata of

160 vegetation, plant species, percent of total and green coverage vegetation, and the

161 number of Spartina alterniflora spikes (i.e., inflorescences). The vegetation data for

162 each transect came from the average of two squares $(1 * 1 \mathrm{~m})$ randomly located along

163 transect. All vegetation surveys were made in vegetated areas. We assumed that the

164 vegetation height and cover represented the main components of the habitat structure in

165 marsh ecosystems (Cardoni et al., 2007).

166 The null hypothesis of no difference in bird richness and abundance and vegetation

167 characteristics (height of vegetation, percent coverage of Spartina alterniflora and spike

168 density) among the three sites at different distances of the sewage discharge source were

169 evaluated by using a one-way ANOVA for each sampling date. An a posteriori LSD

170 Fischer test was used to identify differences, when necessary (Zar, 1999). The null

171 hypothesis of no difference in vegetation characteristics between seasons was evaluated

172 by using a t-test (Zar, 1999). We used simple regression analysis (Zar, 1999) to assess

173 the relationship between nutrient concentrations and vegetation variables, and between

174 bird and vegetation variables.

175 There were dead vegetation depositions of Spartina alterniflora ('wracks') in areas

176 closes to the sewage channel. To evaluate if marshes with different nutrient levels have

177 a different density of wracks, we compared the number of wracks among them using the

178 Google Earth software (http://earth.google.com). The study site was covered by an

179 image from Google Earth with high resolution (date 01-12-2007) where wracks

180 previously geopositioned were easily recognized. Then a portion of 10 ha in the core

181 area was analyzed for each salt marsh (Naposta, Midway and Maldonado). Wracks in

182 each image were digitized to determine the number and the cover area. The density of 
183 wracks was then calculated in each case from the digitized images and differences

184 among sites were evaluated using a Chi-square test (Zar, 1999).

186 3. Results

187 3.1. Nutrient levels

188 There was a nutrient gradient linked to the distance from the sewage discharge

189 source. Ammonium, phosphate and nitrate concentrations were higher at Naposta, the

190 marsh nearer to the sewage discharge, and lower in Midway and Maldonado marshes

191 (ANOVA; Ammonium: $\mathrm{F}_{2,16}=16.90, \mathrm{P}<0.05$; Phosphate: $\mathrm{F}_{2,16}=14.01, \mathrm{P}<0.05$;

192 Nitrate: $F_{2,16}=47.91, P<0.05$; Fig. 2). The same pattern was recorded for the OM

193 content (ANOVA; OM: $\mathrm{F}_{2,16}=4.73$, P < 0.05; Fig. 3).

194 Nutrient concentrations decerased with increasing distances from the sewage

195 discharge source (Ammonium: $\mathrm{r}^{2}=0.34, \mathrm{P}<0.05$; Phosphate: $\mathrm{r}^{2}=0.30, \mathrm{P}<0.05$;

196 Nitrate: $\left.\mathrm{r}^{2}=0.47, \mathrm{P}<0.05\right)$ and no relationship was found between distance and $\mathrm{OM}\left(\mathrm{r}^{2}\right.$ $197=0.17, \mathrm{P}>0.05)$.

199 3.2. Vegetation

200 The only species recorded in all studied sites was the cord grass Spartina

201 alterniflora. The vegetation height and cover were higher in Naposta marsh than in the

202 Midway and Maldonado marshes, both in winter and summer (ANOVA; Vegetation

203 height; winter: $\mathrm{F}_{2,18}=62.85, \mathrm{P}<0.05$; summer: $\mathrm{F}_{2,18}=18.40, \mathrm{P}<0.05$; Vegetation

204 cover; winter: $F_{2,18}=23.79, P<0.05$; summer: $F_{2,18}=10.41, P<0.05$; Fig. 4A and 4B).

205 The vegetation height was higher at the Midway marshes than at the Maldonado marsh

206 only during winter. Plant cover was higher at the Midway marsh than at the Maldonado

207 marsh in the summer. The spike density was higher both in summer and winter in the 
208 Naposta and Midway marshes than in the Maldonado marsh (ANOVA; winter: $\mathrm{F}_{2,18}=$

209 9.92, $\mathrm{P}<0.05$; summer: $\mathrm{F}_{2,18}=8.95, \mathrm{P}<0.05$; Fig. 4C).

210 The total and green cover of S. alterniflora were both higher in summer than winter

211 at the three salt marshes ( $\mathrm{t}$-test; total cover, Naposta, $\mathrm{t}_{12}=2.95, \mathrm{P}<0.05$; Midway, $\mathrm{t}_{12}=$

212 2.67, $\mathrm{P}<0.05$; Maldonado: $\mathrm{t}_{12}=5.18, \mathrm{P}<0.05$; green cover, Naposta, $\mathrm{t}_{12}=10.81, \mathrm{P}<$

213 0.05; Midway, $\mathrm{t}_{12}=4.31, \mathrm{P}<0.001$; Maldonado, $\left.\mathrm{t}_{12}=8.01, \mathrm{P}<0.05\right)$. Vegetation height

214 was better explained by nutrients concentrations (Phosphate, $\mathrm{r}^{2}=0.66, \mathrm{P}<0.05$;

215 Ammonium, $\mathrm{r}^{2}=0.70, \mathrm{P}<0.05$; Nitrate, $\mathrm{r}^{2}=0.84, \mathrm{P}<0.05$, Fig. 5A) than vegetation

216 cover (Phosphate, $\mathrm{r}^{2}=0.51, \mathrm{P}<0.05$; Ammonium, $\mathrm{r}^{2}=0.51, \mathrm{P}<0.05 ;$ Nitrate, $\mathrm{r}^{2}=$ $2170.66, \mathrm{P}<0.05)$.

218 There were 13 wracks (7.5\% of 10 ha marsh) at the Naposta marsh, 3 wracks (1.9

$219 \%$ of 10 ha marsh) at the Midway marsh, and none at the Maldonado marsh (Chi-Square $220=227.63, \mathrm{df}=1, \mathrm{P}<0.05)$.

221

222

3.3. Birds

223

Nineteen bird species were recorded in the three sites (Table 1). The total bird species recorded for each distance were 16, 12 and 5 species in the Naposta, Midway and Maldonado marshes, respectively. Seventy-two percent of all birds, at all sites were at the Naposta marsh (the nearest area of the discharge source) and only 23 and $5 \%$ at the Midway and at Maldonado marshes, respectively. The bird abundance was always

228 higher in Naposta marsh than in Maldonado marsh (Table 2 and Fig. 6). The bird 229 abundance exclusive of the Yellow-winged Blackbird also was higher in the Naposta

230 marsh than in the Maldonado marsh for all months (Table 2 and Fig. 6). In some months 231 it was also higher in the Naposta marsh than in the Midway marsh (Table 2 and Fig. 6).

232 The bird richness was always higher in the Naposta marsh (Fig. 6). 
The Yellow-winged Blackbird (Agelaius thilius) was the most abundant bird

234 species, with $72 \%$ of the total bird abundance. However, $80 \%$ of the Yellow-winged

235 Blackbird abundance was recorded only in the Naposta marsh. Other bird species

236 associated with tall grass (without considering Yellow-winged Blackbird; Table 1) were

237 only recorded at the Naposta marsh, the site with higher values of S. alterniflora cover

238 and height. Bird species associated with open areas (i.e., short grass and mud flats;

239 Table 1) had a higher abundance in the Naposta marsh than in the Midway and

240 Maldonado marshes in four of ten months, and were higher in two months in the

241 Naposta and Midway marshes than in Maldonado marsh (Table 2). It should be noted

242 that there were more wracks in the Naposta marsh than in the others two marshes.

243 Bird abundance and richness were both positively correlated with height of Spartina

244 alterniflora (Abundance* $S$. alterniflora height: $\mathrm{r}^{2}=0.65, \mathrm{P}<0.05$, Fig 5B; Richness* $S$.

245 alterniflora height: $\left.\mathrm{r}^{2}=0.28, \mathrm{P}<0.05\right)$. Bird abundance was also explained by $S$.

246 alterniflora cover $\left(\mathrm{r}^{2}=0.53, \mathrm{P}<0.05\right)$. Bird richness was not correlated with vegetation

247 cover $\left(r^{2}=0.17, P>0.05\right)$. Bird abundance without Yellow-winged Blackbird (species

248 that represented the $72 \%$ of the total bird abundance) was correlated with vegetation

249 cover and height (Abundance without Yellow-winged Blackbird*S. alterniflora height:

$250 \quad r^{2}=0.47, \mathrm{P}<0.05 ;$ Abundance without Yellow-winged Blackbird* S. alterniflora

251 cover: $\left.\mathrm{r}^{2}=0.41, \mathrm{P}<0.05\right)$.

253 4. Discussion

254 The concentration of ammonium, nitrate and phosphate and the percent of organic

255 matter content were higher in marshes nearest to the sewage discharge source.

256 Vegetation physiognomy, bird composition and abundance changed along a gradient of

257 nutrient concentrations in a S. alterniflora marsh. Bird species and bird abundance 
258 increased near the nutrient discharge source. These changes were associated with the

259 increase of height and cover of the S. alterniflora. The same pattern was recorded

260 among height and cover of S. alterniflora with nutrient concentration. This study is one

261 of the first that evaluates the relationship between nutrient enrichment and actual effects

262 on higher trophic levels, such as birds.

263 The main effect of the discharge seems to be constrained relatively near to the

264 nutrient source, given that nutrients and vegetation structure decreased abruptly, being

265 approximately 50 percent lower within $\sim 250$ meters of the sewage sourcewater. These

266 patterns suggest that the S. alterniflora marsh is a 'sink' for anthropogenic nutrients (the

267 concentration of ammonium decreased from 453 to $214 \mu \mathrm{M}$ for, phosphate from 442 to

$268221 \mu \mathrm{M}$, nitrate from 35 to $19 \mu \mathrm{M}$, the OM decreased from 15 to $9 \%$ ), vegetation cover

269 declined from 85 to $75 \%$, and height dropped from 87 to $46 \mathrm{~cm}$. These results suggest

270 that perhaps Spartina alterniflora could be used as an ecological engineering organism

271 to remediate eutrophicated salt marsh areas (Mitsch and Jørgensen, 1989; Marques et

272 al., 2003).

273 The increase in habitat structure nearest the sewage outfall was exploited by bird

274 species that use the neighboring interior and coastal habitats such as $S$. densiflora

275 marsh, fresh marshes, upland shrubby habitats. These neighboring habitat species could

276 take advantage of the increased refuge (e.g., species associated to dense grassland as

277 Bay-capped Wren-Spinetail, Spartonoica maluroides; Cardoni et al., 2007; Mitchell et

278 al., 2006), food (e.g., partially granivorous species as the Yellow-winged Blackbird;

279 Darrieu et al., 2001) and nesting sites (Mitchell et al., 2006; Cardoni D.A. and Isacch

280 J.P., unpublished data). On the other hand, the open areas generated by mat deposition

281 were used mainly by waders and shorebirds at the Midway marsh, and by passerines

282 and shorebirds in the marshes located near the sewage discharge outfall. The 
283 eutrophication at the Bahía Blanca marshes may, therefore, be producing a bottom-up

284 effect that directly affects vegetation, and indirectly affects organisms higher in the 285 trophic web, such as birds.

286 The species using marshes changed with seasons. The Bar-winged Cinclodes

287 (Cinclodes fuscus) and Rufous-backed Negrito (Lessonia rufa) were found during

288 winter, while the Bay-capped Wren-Spinetail and Grassland Yellow-Finch (Sicalis

289 luteola) were recorded in the summer. Other birds, such as the Yellow-winged

290 Blackbird, Correndera Pipit (Anthus correndera) and Chimango Caracara (Milvago

291 chimango) were present all year. This pattern suggests that marshes with higher nutrient

292 levels support the seasonal or annual requirements for different bird species, which

293 would be using the salt marsh to nest, feed and/or rest.

294 The southern salt marshes from the SW Atlantic (Bahía Blanca, Bahía San Blas, San

295 Antonio Oeste; Isacch et al., 2006) are dominated in the lower tidal elevation by

296 monospecific grasslands of S. alterniflora, which have a relative short height and cover

297 (Isacch et al., 2007), and are used occasionally by few bird species (Maldonado marsh

298 in this study, Table 1; Isacch J.P., pers. obs.). Vegetation structure (e.g., height and

299 cover) is an important factor for bird habitat selection, determining the bird abundance

300 and richness in many different ecosystems around the world (MacArthur and

301 MacArthur, 1961; Wiens, 1973; Roth, 1976). A number of bird species move from

302 adjacent habitats into the Bahía Blanca salt marsh when the structure changes in

303 response to the increased nutrients. This is what happens with the Pale-breasted

304 Spinetail (Synallaxis albescens) from shrublands, Bay-capped Wren-Spinetail, and

305 Grass Wren (Cistothorus platensis) from the S. densiflora marsh, and Many-colored

306 Rush-Tyrant (Tachuris rubrigastra), Wren-like Rushbird (Phleocryptes melanops) and

307 Yellow-winged Blackbird from freshwater marshes. The Yellow-winged Blackbird was 
308 also recorded in low nutrient marshes, but the number of individuals was 18 times

309 higher in the high nutrient marshes. Increased bird abundance and richness could not

310 only be the result of vegetation structure, but also due to increased food availability.

311 Nutrient enrichment has several effects on the salt marsh food web. It may increase the

312 nutritive value of plants (protein, lipids, soluble carbohydrates in S. alterniflora; Biudes

313 and Camargo, 2006), the abundance and biomass of macroinfaunal species (Sardá et al.,

314 1996), and the insect abundance (Bertness et al., 2008), thus causing indirect effects on

315 the upper food web organism, such as birds and fishes (Raffaelli, 1999). Nutrient

316 concentrations can affect birds differentially depending on the environmental

317 characteristics or resources selected by each particular species or guild, such as benthic

318 invertebrate-feeders (e.g., shorebirds, Correndera Pipit, Bar-winged Cinclodes),

319 vegetation insect-feeders (e.g., Bay-capped Wren-Spinetail, Wren-like Rushbird), seed

320 eaters (e.g., Yellow-winged Blackbird, Grassland Yellow-Finch, Great Pampa-Finch,

321 Embernagra platensis) and generalist predators (Caracara Chimango). Our results show

322 that salt marshes with nutrient enrichment had higher densities of S. alterniflora spikes

323 than in salt marshes with relative low nutrient levels. The increase in the abundance of

324 seed-eater species, especially the Yellow-winged Blackbird, may result from the

325 increment in the spike density of S. alterniflora. Reductions in the abundance of benthic

326 infauna were observed close to a sewage output following an increase in sewage output

327 (Hall et al., 1999). Some benthic invertebrates, however, notably annelids, are abundant

328 close to sources of nutrient pollution (Green et al., 1990), favouring ground feeder birds.

329 Increased arthropods in grass dominated habitats had been associated with increased

330 complexity of plant architecture (Gibson et al., 1992; Dennis et al., 2001), and the

331 increase of vegetation height (Morris and Plant, 1983; Dennis et al., 1997) and

332 heterogeneity (Dennis et al. 1998; Vickery et al., 2001). Specifically, the number of 
333 herbivore insects increased when the nutritional quality of salt marsh plants improved as

334 a result of higher nutrient loading increased (Vince et al. 1981). All of this evidence

335 suggests that we might expect increased arthropod availability for birds with an increase

336 of nutrient loadings to marshes. There is, therefore, an alternative possibility to explain

337 why there are more birds in the high-nutrient marsh.

338 The dramatic increase of the raptor Chimango Caracara could be related to the

339 increase of smaller birds and insects, two of the main prey of this species (Biondi et al.,

340 2005). We suspect that Chimango Caracara is taking advantage of the disturbance, since

341 the capacity and plasticity of this species to use new habitats has been demonstrated

342 (Pedrana et al., 2008; Bellocq et al., 2008), including a remarkable ability to obtain food

343 in novel situations (Biondi et al., 2008).

344 The association between increased seed production and the increase of seed-eater

345 birds was also recorded in other SW Atlantic salt marsh, but was explained as a result of

346 the indirect effect of the burrowing crab (Neohelice granulata) on S. densiflora marsh

347 (Cardoni et al., 2007). This crab, because it builds caves, generates higher sediment

348 water content and lower sediment hardness (Bortolus et al., 2004; Fanjul et al., 2007),

349 and increases the nitrification-denitrification rate when soil oxygenation increases

350 (Botto et al., 2005; Fanjul et al., 2007). The result is that plants allocate more energy to

351 sexual reproduction when crabs are prevalent. Thus, different sources (i.e., natural and

352 anthropogenic) of enhanced nutrient conditions (i.e., crabs caves and anthropogenic

353 discharges) on different salt marsh plants may cause an increase of seed-eater bird

354 species when compared with undisturbed salt marshes where insectivorous birds are the

355 dominant trophic guild (Isacch et al., 2004; Cardoni et al., 2007).

356 Biomass generated by increased nutrient loading increases detrital production

357 (Gonzalez Trilla et al., 2009) which also increases the generation of wracks. Marshes 
358 located close to the sewage showed higher number of wracks in the S. alterniflora

359 marsh, generating higher landscape heterogeneity. Wracks, generates areas devoid of

360 vegetation that are used by ground birds (e.g., Correndera Pipit, Bar-winged Cinclodes).

361 Similar to the pattern recorded for the plant physiognomy, wracks may facilitate the use

362 of the salt marsh by species from upper open habitats. This is a small scale disturbance,

363 which is known to be important in maintaining species diversity (e.g. Grime, 1977;

364 Grubb, 1977). Indeed, one of the well known cases is the effect produced by a tree fall

365 in the rainforest, generating gaps that increase light penetration and therefore also

366 increases plant diversity (Brawn et al. 2001). In our system, gaps produced by wracks

367 generate habitat for open habitat bird species.

368 Salt marshes could be vulnerable if the nutrient delivery is discharged without

369 management, given that it can ultimately degrade the structure of the marsh itself

370 (Levine et al., 1998; Bertness et al., 2002; Crain, 2007). The sewage discharge into the

371 Bahía Blanca estuary is being done without any treatment. In an advanced

372 eutrophication process, the production of high amount of detritus could be generating a

373 negative effect in marsh ecosystems (Hall et al., 1999) by several processes such as

374 decreasing the local or regional biodiversity, increased competitive advantage of

375 invasive species, loss of nutrient retention capacity or, shifts between "clear water"

376 macrophyte-dominated systems to turbid phytoplankton-dominated systems (see EPA,

3772008 for a review). The sewage effluent may also create conditions favoring parasites

378 on fishes and wading birds (Coyner et al., 2002, 2003). However, the growth of the

379 aboveground biomass may be limited by nitrogen, but the belowground biomass may

380 not be. The belowground biomass accumulation is what keeps the marsh at sea level

381 and its biomass may be limited by phosphorus (Darby and Turner, 2008a,b). If the 
382 belowground biomass is compromised, then the long-term sustainability of the marsh

383 may be harmed (Turner et al., 2009).

384 All the negative effects described above were not assessed in our study system, and

385 we recognize that increases of some bird species, should be taken with caution and not

386 as an overall beneficial effect of sewage discharges on the environment. Most bird

387 species recorded in the eutrophicated marsh were common (Yellow-winged Blackbird)

388 or extremely generalist species (Chimango caracara), without a specific conservation

389 value. However, the movement of species into the eutrophicated marsh can turn in an

390 ecological trap for ground or nearground nesting. Spartina alterniflora grows in the

391 lower part of the intertidal, which in turn make nests vulnerable to frequent extreme

392 floods by storms (Cardoni D.A and Isacch J.P. unpublished data).

393 In summary, our results show how local increments of nutrients generate direct and

394 indirect changes in the salt marsh ecosystem. There are direct changes, as those caused

395 on the vegetation physiognomy, and indirect changes in the composition and abundance

396 of the bird assemblage.

397

398 5. Acknowledgments

399 This work was supported by grants and fellowships from ANPCYT, CONICET and

400 Universidad Nacional de Mar del Plata to O. Iribarne.

401 


\section{Literature cited}

Bertness, M.D., Crain, C., Holdredge, C., Sala, N., 2008. Eutrophication and consumer control of New England salt marsh primary productivity. Conservation Biology 22, 131-139.

Bertness, M.D., Ewanchuk, P., Silliman, B.R., 2002. Anthropogenic modification of New England salt marsh landscapes. Proceedings of the National Academy of Sciences, USA. 99, 1395-1398.

Bellocq, M.I., Filloy, J., Garaffa, P.I, 2008. Influence of agricultural intensity and urbanization on the abundance of the raptor Chimango Caracara (Milvago chimango) in the Pampean region of Argentina. Annales Zoologici Fennici 45, 128134.

Bibby, C.J., Burgess, N.D., Hill, D., 1997. Bird Census Techniques. Academic Press, London, U.K.

Biondi, L.M., Bó, M.S., Favero, M., 2005. Dieta del Chimango (Milvago chimango) durante el periodo reproductivo en el sudeste de la provincial de Buenos Aires, Argentina. Ornitología Neotropical 16, 31-42.

Biondi, L.M., Bó, M.S., Vassallo, A.I., 2008. Experimental assessment of problem solving in Milvago chimango (Aves: Falconiformes). Journal of Ethology 26, 113118.

Biudes, J.F.V., Camargo, A.M., 2006. Changes in biomass, chemical composition and nutritive value of Spartina alterniflora due to organic pollution in the Itanhaém River Basin (SP, Brazil). Brazilian Journal of Biology 66, 781-789.

Block, W.M., Brennan, L.A., 1993. The habitat concept in ornithology: Theory and applications. Current Ornithology 11, 35-89.

Bortolus, A., Laterra, P., Iribarne, O., 2004. Crab-mediated phenotypic changes in 
Spartina densiflora Brong. Estuarine, Coastal and Shelf Science 59, 97-107.

Botto, F., Valiela, L., Iribarne, O., Martinetto, P., Alberti, J., 2005. Effect of burrowing crabs in isotope signatures of sediment, primary producers, and the food web in SW Atlantic salt marshes. Marine Ecology Progress Series 293, 155-164.

Brawn, J.D., Robinson, S.K., Thompson, F.R., 2001. The role of disturbance in the ecology and conservation of birds. Annual Review of Ecology and Systematic 32, $251-76$.

Buchanan, G.M., Grant, M.C., Sanderson, R.A., Pearce-Higgins, J.W., 2006. The contribution of invertebrate taxa to moorland bird diets and the potential implications of land-use management. Ibis 148, 615-628.

Cardoni, D.A., Isacch, J.P., Iribarne, O.O., 2007. Indirect effects of the intertidal burrowing Crab Chasmagnathus granulatus in the habitat use of Argentina's South West Atlantic salt marsh birds. Estuarine and Coast 30, 382-389.

Costa, C.S.B., Iribarne, O.O., Farina, J.M., 2009. Human impacts and threats to the conservation of South American salt marshes, in: Silliman, B.R., Grosholz, E.D., Bertness, M.D., (Eds), Human impacts on salt marshes. A global perspective, University of California Press, Los Angeles, USA, pp 337-359.

Coyner, D.F., Spalding, M.G., Forrester, D.J., 2002. Epizootiology of Eustrongylides ignotus in Florida: Distribution, density, and natural infections in intermediate hosts. Journal of Wildlife Diseases 38, 483-499.

Coyner, D.F., Spalding, M.G., Forrester, D.J., 2003. Influence of treated sewage on infections of Eustrongylides ignotus (Nematoda: dioctophymatoidea) in eastern mosquitotish (Gambusia holbrooki) in an urban watershed. Comparative Parasitology 70, 205-210. 
Craft, C.B., Vymazal, J., Richardson, C.J., 1995. Response of Everglades plant communities to nitrogen and phosphorus additions. Wetlands 15, 258-271.

Crain, C.M, 2007. Shifting nutrient limitation and eutrophication effects in marsh vegetation across estuarine salinity gradients. Estuarines and Coasts 30, 26-34.

Daleo, P., Alberti, J., Canepuccia, A., Escapa, M., Fanjul, E., Silliman, B.R., Bertness, M.D., Iribarne, O.O., 2008. Mycorrhizal fungi determine salt marsh plant zonation depending on nutrient supplies. Journal of Ecology 96, 431-437.

Darby, F.A., Turner, R.E., 2008a. Below- and aboveground Spartina alterniflora production in a Louisiana salt marsh. Estuaries and Coasts 31, 223-231.

Darby, F.A., Turner, R.E., 2008b. Consequences of eutrophication to salt marsh roots, rhizomes, and soils. Marine Ecology Progress Series 363, 63-70.

Darrieu, C.A., Camperi, A.R., Soave, G.E., Cicchino, A., 2001. Ecología alimentaría del Varillero Ala Amarilla (Agelaius thilius) en ambientes ribereños de la provincia de Buenos Aires. Ornitología Neotropical 12, 205-214.

Deegan, L.A., Hughes, J.E., Rountree, R.A., 2000. Salt marsh ecosystem support of marine transient species, in: Weinstein, M.P., Kreeger, D.A. (Eds.), Concepts and controversies in tidal marsh ecology. Kluwer Academic Publisher, Amsterdam, The Netherlands, pp 333-365.

Deegan, L.A., 2002. Lessons learned: The effects of nutrient enrichment on the support of nekton by seagrass and salt marsh ecosystems. Estuaries 25, 727-742.

Dennis, P., Young, M.R., Bentley, C., 2001. The effects of varied grazing management on epigeal spiders, harvestmen and pseudoscorpions of Nardus stricta grassland in upland Scotland. Agriculture, Ecosystems and Environment 86, 39-57. 
Dennis, P., Young, M.R., Gordon, I.J., 1998. Distribution and abundance of small insects and arachnids in relation to structural heterogeneity of grazed, indigenous grasslands. Ecological Entomology 23, 253-264.

Dennis, P., Young, M.R., Howard, C.L., Gordon, I.J., 1997. The response of epigeal beetles (Col. Carabidae, Staphylinidae) to varied grazing regimes on upland Nardus stricta grasslands. Journal of Applied Ecology 34, 433-443.

EPA, 2008. Nutrient Criteria Technical Guidance Manual: Wetlands. EPA-822-B-08001.

Fanjul, E., Grela, M.A., Iribarne, O.O., 2007. Effects of the dominant SW Atlantic intertidal burrowing crab Chasmagnathus granulatus on sediment chemistry and nutrient distribution. Marine Ecology Progress Series 341, 177-180.

Fretwell, S.D., Lucas, H., 1970. On territorial behavior and other factors influencing habitat distribution in birds. Acta Biotheoretica 19, 16-52.

Friedrichs, C.T., Perry, J.E., 2001. Tidal salt marsh morphodynamics: A synthesis. Journal of Coastal Research 27, 7-37.

Gibson, C.W.D., Brown, V.K., Losito, L., McGavin, G.C., 1992. The response of invertebrate assemblies to grazing. Ecography 15, 166-176.

Gonzalez Trilla, G., Kandus, P., Negrin, V., Vicari, R., Marcovecchio, J., 2009. Tiller dynamic and production on a SW Atlantic Spartina alterniflora marsh. Estuarine, Coastal and Shelf Science 85, 126-133.

Green, B.W., Alvarenga, H.R., Phelps, R.P., Espinoza, J., 1990. Pond Dynamics /Aquaculture Collaborative Research Data Reports. Honduras: Cycle I of The Global Experiment, Vol. 6, No. 1. Pond Dynamics/Aquaculture, Collaborative Research Support Program, Office of International Research and Development, Oregon State University, Corvallis, OR, 93 pp 
Grime, J.P., 1977. Evidence for the existence of three primary strategies in plants and its relevance to ecological and evolutionary theory. American Naturalist 111, 11691195.

Group of Experts on the Scientific Aspects of Marine Pollution (GESAMP), 1990. State of the marine environment. Reports and studies number 39. United Nations Environmental Program.

Grubb, P.J., 1977. The maintenance of species-richness in plant communities; The importance of the regeneration niche. Biological Reviews 52,107-145.

Hall, R.I., Leavittleavitt, P.R., Dixit, A.S., Smol, J.P., 1999. Effects of agriculture, urbanization, and climate on water quality in the northen Great Plains. Limnology and Oceanography 44, 739-756.

Harper, D., 1995. Eutophication of Freshwaters: Principles, problems and restoration. Chapman and Hall, London, 327p.

Hildén, O., 1965. Habitat selection in birds. A review. Annales Zoologici Fennici 2, 53 75.

Hoyer, M., Canfield Jr., D.E., 1990. Limnological factors influencing bird abundance and species richness on Florida lakes. Lake and Reservoir Management 6, 133-142.

Hoyer, M., Canfield Jr., D.E., 1994. Bird abundance and species richness on Florida lakes: Influence of trophic status, lake morphology, and aquatic macrophytes. Hydrobiologia 297/280, 107-119.

Isacch, J.P., Costa, C.S.B., Rodríguez-Gallego, L., Conde, D., Escapa, M., Gagliardini, D.A., Iribarne, O.O., 2006. Distribution of saltmarsh plant communities associated with environmental factors along a latitudinal gradient on the south-west Atlantic coast. Journal of Biogeography 33, 888-900. 
Isacch, J.P., Holz, S., Ricci, L., Martínez, M., 2004. Post-fire vegetation change and bird use of a salt marsh in coastal Argentina. Wetlands 24, 235-243.

Isacch, J.P., Karzembaun, H., Kitlein, M., Iribarne, O., Escapa, M., Gagliardini, D.A., 2007. Generalization across space in the relationship between cord grass (Spartina alterniflora) biomass and reflectance data by using Landsat ETM+ images. Proceedings of the Congreso de la Sociedad Española de Teledetección, pp. 1-6.

Levine, J., Brewer, S.J., Bertness, M.D., 1998. Nutrients, competition and plant zonation in a New England salt marsh. Journal of Ecology 86, 285-292.

Lopes, R.J., Pardal, M.A., Múrias, T., Cabral, J.A., Marques, J.C., 2006. Influence of macroalgal mats on abundance and distribution of dunlin Calidris alpina in estuaries: A long-term approach. Marine Ecology Progress Series 323, 1-20.

Mac Arthur, R.H., Mac Arthur, J.W., 1961. On bird species diversity. Ecology 42, 594598.

Macnally, R.C., 1990. The roles of floristics and physiognomy in avian community composition. Australian Journal of Ecology 15, 321-327.

Martinetto, P., Daleo, P., Isacch, J.P., Escapa, M., Alberti, J.,. Botto, F., Fanjul, M.E., Piriz, M.L., Ponce, G. Casas, G., Iribarne, O.O., 2010. High abundance and diversity of consumers associated to eutrophic areas in a semi-desert macrotidal coastal ecosystem in Patagonia, Argentina. Estuarine Coastal and Shelf Sciences $88,357-364$.

McCarty, J.P., 1997. Aquatic community characteristics influence the foraging patterns of Tree Swallows. Condor 99, 210-213.

Mendelssohn, I.A., 1979. Nitrogen metabolism in the height forms of Spartina alterniflora in North Carolina. Ecology 60, 574-584. 
Minchinton, T.E., 2002. Disturbance by wrack facilitates spread of Phragmites australis in a coastal marsh. Journal of Experimental Marine Biology and Ecology 281, 89107.

Mitchell, L.R., Gabrey, S., Marra, P.P., Erwin, R.M., 2006. Impacts of marsh management on coastal-marsh bird habitats. Studies in Avian Biology 32, 155-175.

Mitsch, W.J., Jørgensen, S.E., (Eds.), 1989. Ecological Engineering. An Introduction to Ecoechnology. John Wiley \& Sons, New York, pp. 472.

Mitsch, W.J., Gosselink, J.G., 2000. Wetlands. John Wiley and Sons, Inc., New York, pp. 920 .

Montesarchio, L.A., Lizasoain, W.O., 1981. Dinámica sedimentaria en la denominada ría de Bahía Blanca. Contribución científica 58. Instituto Argentino de Oceanografía, 208pp, in: Piccolo, M.C., Hoffmeyer, M.S. (Eds), Ecosistema de estuario de Bahía Blanca, Bahía Blanca, Argentina, 31 pp.

Morris, M.G., Plant, R., 1983. Responses of grassland invertebrates to management by cutting. V. Changes in Hemiptera following cessation of management. Journal of Applied Ecology, 20, 157-177.

Nebbia, A.J., Zalba, S.M., 2007. Comunidades Halófilas de la costa de la Bahía Blanca (Argentina): Caracterización, mapeo y cambios durante los últimos cincuenta años. Boletín de la Sociedad Argentina de Botánica 42, 261-271.

Nilsson, S.G., Nilsson I.N., 1978. Breeding bird community densities and species richness in lakes. Oikos 31, 214-221.

Pedrana, J., Isacch, J.P., Bó, M.S., 2008. Habitat relationships of diurnal raptors at local and landscape scales in southern temperate grasslands of Argentina. Emu 108, 301310. 
Raffaelli, D., 1999. Nutrient enrichment and trophic organisation in an estuarine food web. Acta Oecologica 20, 449-461.

Robledano, F., Pagán, I., Calvo, J.F., 2008. Waterbirds and nutrient enrichment in Mar Menor lagoon, a shallow coastal lake in southeast Spain. Lakes and Reservoirs: Research and Management 13, 37-49.

Rönkä, M.T.H., Saari, C.L.V., Lehikoinen, E.A., Suomela, J., Häkkilä, K., 2005. Environmental changes and population trends of breeding waterfowl in northern Baltic Sea. Annales Zoologici Fennici 42, 587-602.

Rosa, S., Palmeirin, J.M., Moreira, F., 2003. Factors affecting waterbird abundance and species richness in an increasingly urbanized area of the Tagus estuary in Portugal. Waterbirds 26, 226-232.

Roth, R.R., 1976. Spatial heterogeneity and bird species diversity. Ecology 57, 773-782.

Sardá, R., Valiela, I., Foreman, K., 1996. Decadal shifts in a salt marsh macroinfaunal community in response to sustained long-term experimental nutrient enrichment. Journal of Experimental Marine Biology and Ecology 205, 63-81.

Solórzano, L., 1969. Determination of ammonia in natural waters by the phenolhypochlorite method. Limnology and Oceanography 14, 799-801.

Steele, B.B., 1993. Selection of foraging and nesting sites by Black-throated blue Warblers - their relative influence on habitat choice. Condor 95, 568-579.

Strickland, J.D.H., Parsons, T.R., 1968. A practical handbook of sea water analysis. Bulletin of Fisheries Research Board of Canada 167, 1-311.

Turner, R.E., Howes, B.L., Teal, J.M., Milan, C.S., Swenson, E.M., Goehringer-Toner, D., 2009. Salt marshes and eutrophication: An unsustainable outcome. Limnology and Oceanography 54, 1634-1642. 
UNEP, 2006. Marine and coastal ecosystems and human wellbeing: A synthesis report based on the findings of the Millennium Ecosystem Assessment. UNEP. 76pp

Vaithiyanathan, R., Richardson, C., 1997. Nutrient in the Everglades: Examination along the eutrophication gradient. Science of the Total Environment 205, 81-95.

Valiela, I., 2006. Global Coastal Change. Blackwell Pub, Malden, EEUU.

Valiela, I., Teal, J.M., 1974. Nutrient limitation in salt marsh vegetation, in: Reimold, R.J., Queen W.H. (Eds.), Ecology of Halophytes. Academic Press, New York, pp. $547-563$.

Valiela, I., Rietsma, C.S., 1995. Disturbance of salt marsh vegetation by wrack mats in Great Sippewissett marsh. Oecologia 102, 106-112.

Valiela, I., Teal, J.M., Volkmann, S., Shafer, D., 1978. Nutrient and particulate fluxes in a salt marsh ecosystem: Tidal exchanges and inputs by precipitation and groundwater. Limnology and Oceanography 23, 798-812.

Vickery, J.A., Tallowin, J.R., Feber, R.E., Asteraki, E.J., Atkinson, P.W., Fuller, R.J., Brown, V.K., 2001. The management of lowland neutral grasslands in Britain: Effects of agricultural practices on birds and their food resources. Journal of Applied Ecology 38, 647-664.

Vince, S.W., Valiela, I., Teal, J.M., 1981. An experimental study of the structure of herbivorous insect communities in a salt marsh. Ecology 62, 1662-1678.

Vitousek, P.M., Aber, J., Bayley, S.E., Howarth, R.W., Likens, G.E., Matson, P.A., Schindler, D.W., Schlesinger, W., Tilman, G.D., 1997. Human alteration of the global nitrogen cycle: causes and consequences. Ecological Application 7, 737-750. Wiens, J.A., 1973. Pattern and process in grassland bird communities. Ecological Monographs 43, 237-270. 
Wilson, M.F., 1974. Avian community organization and habitat structure. Ecology 55, 1017-1029.

Wolanski, E., 2007. Estuarine Ecohydrology. Elsevier, Amsterdam, The Netherlands

Zar, J.H., 1999. Biostatistical analysis. Prentice-Hall Inc., Englewood Cliff, New Jersey.

\section{FIGURE CAPTIONS}

Figure 1: Top: Bahía Blanca (Argentina) during a low tide. White doted lines enclose the amplified area included in the bottom image. The black dot represents the location of the sewage discharge source. The inset in the lower left shows the location of the study area in Argentina. Bottom: a detail of the sewage discharge source and the three sites sampled (A, B and C) in Spartina alterniflora saltmarshes from Bahía Blanca. The four main habitats identified here are uplands (white), saltmarshes (light grey), mudflat (dark grey) and sea (black). Letters indicate the location of the three sites studied: (A) the Naposta marsh located near the discharge site; (B) the Midway marsh, located 200 meters from the discharge source; and (C) the Maldonado marsh $10 \mathrm{Km}$ from the discharge source.

Figure 2: The concentration of ammonium (A), phosphate (B) and nitrate (C) in sediment in three salt marshes at different distances from the sewage discharge source (Naposta, Midway, Maldonado; see Fig. 1). The box plots are constructed with the limits of boxes being the 75 th and 25 th percentiles, and lines represent the minimum 
and maximum value; the line inside the boxes is the median value. Different letters in the upper the plot represent significant differences as determinated using an a posteriori LSD test $(\mathrm{P}<0.05)$.

Figure 3: Percentages of organic matter $(\mathrm{OM})$ in sediments in three salt marshes at different distances to the sewage source (Naposta, Midway, Maldonado; see Fig. 1).

Figure 4: Height (A), cover (B) and spike density (C) of Spartina alterniflora in three salt marshes at different distances to the sewage discharge source (Naposta, Midway, Maldonado; see Fig. 1).

Figure 5: Relationship between vegetation height and nitrate concentration (A), and vegetation height and total number of individuals of birds (B).

Figure 6: Number of individuals (A), number of individuals without Yellow-winged Blackbird and species of birds (B) in three salt marshes at different distances from the sewage discharge (Naposta, Midway, Maldonado; see Fig. 1). The statistical data are in Table 1. 
$\underline{\text { Research highlights }}$

Saltmarshes are increasingly affected by sewage discharge.

Nutrient changes the vegetation physiognomy, increasing the habitat complexity.

Bird composition and abundance increase in high nutrient saltmarshes. 


\begin{tabular}{|c|c|c|c|c|c|}
\hline & $\begin{array}{l}\text { Naposta } \\
\text { (High) }\end{array}$ & $\begin{array}{c}\text { Midway } \\
\text { (Intermediate) }\end{array}$ & $\begin{array}{c}\text { Maldonado } \\
\text { (Low) }\end{array}$ & Total & $\begin{array}{c}\text { Habitat } \\
\text { association }\end{array}$ \\
\hline \multicolumn{6}{|l|}{ Passerines species } \\
\hline Yellow-winged Blackbird, Agelaius thilius & 1183 & 229 & 63 & 1475 & TG \\
\hline Correndera Pipit, Anthus correndera & 56 & 21 & 4 & 81 & SG \\
\hline Bar-winged Cinclodes, Cinclodes fuscus & 10 & 3 & 0 & 13 & SG \\
\hline Wren-like Rushbird, Phleocryptes melanops & 13 & 0 & 0 & 13 & TG \\
\hline Rufous-backed Negrito, Lessonia rufa & 1 & 10 & 0 & 11 & SG \\
\hline Great Pampa-Finch, Embernagra platensis & 8 & 0 & 0 & 8 & TG \\
\hline Red-capped Wren-Spinetail, Spartonoica maluroides & 7 & 0 & 0 & 7 & TG \\
\hline Many-colored Rush-Tyrant, Tachuris rubrigastra & 6 & 0 & 0 & 6 & TG \\
\hline Pale-breasted Spinetail, Synallaxis albescens & 5 & 0 & 0 & 5 & TG \\
\hline Grassland Yellow-Finch, Sicalis luteola & 2 & 0 & 0 & 2 & TG \\
\hline Grass Wren, Cistothorus platensis & 1 & 0 & 0 & 1 & TG \\
\hline Long-tailed Meadowlark, Sturnella loyca & 0 & 1 & 0 & 1 & TG \\
\hline \multicolumn{6}{|l|}{ Raptors } \\
\hline Milvago Chimango, Caracara chimango & 175 & 68 & 25 & 268 & SG,TG,MF \\
\hline Long-winged Harrier, Circus buffoni & 1 & 1 & 1 & 3 & TG \\
\hline Southern Crested-Caracara, Caracara planctus & 1 & 1 & 0 & 2 & $\mathrm{SG}, \mathrm{TG}$ \\
\hline \multicolumn{6}{|l|}{ Waders and shorebirds } \\
\hline South America Stilt, Himantopus melanurus & 4 & 122 & 0 & 126 & MF \\
\hline Southern Lapwing, Vallenus chilensis & 3 & 8 & 0 & 11 & $\mathrm{SG}, \mathrm{MF}$ \\
\hline Snowy Egret, Egretta thula & 0 & 3 & 2 & 5 & $\mathrm{MF}$ \\
\hline Lesser Yellowlegs, Tringa flavipes & 0 & 2 & 0 & 2 & MF \\
\hline
\end{tabular}


${ }^{1}$ Relative abundance of birds (total number of individuals) by species recorded in three areas with different nutrient levels in the Bahía Blanca saltmarsh, Argentina. Habitat association: TG: tall grassland; SG: short grassland; MF: mud flat. Bird-habitat association was based on studies of similar habitats in the region (Comparatore et al., 1996; Isacch and Martínez, 2001; Isacch et al., 2001, 2004; Cardoni et al., 2007). 
ACCEPTED MANUSCRIPT

\begin{tabular}{|c|c|c|c|c|c|c|c|c|}
\hline & \multicolumn{2}{|c|}{ Total richness } & \multicolumn{2}{|c|}{ Total abundance } & \multicolumn{2}{|c|}{$\begin{array}{l}\text { Abundance without } \\
\text { Yellow-winged } \\
\text { Blackbird } \\
\end{array}$} & \multicolumn{2}{|c|}{$\begin{array}{c}\text { Species associated to } \\
\text { open gaps }\end{array}$} \\
\hline & $\mathrm{F}$ & $\mathrm{P}$ & $\mathrm{F}$ & $\mathrm{P}$ & $\mathrm{F}$ & $\mathrm{P}$ & $\mathrm{F}$ & $\mathrm{P}$ \\
\hline July & 7.3 & 0.007 & 32 & 0.00001 & 6.57 & 0.011 & 12.1 & 0.001 \\
\hline August & 8.3 & 0.003 & 17.2 & 0.00007 & 6.69 & 0.007 & 6.4 & 0.008 \\
\hline September & 5.5 & 0.01 & 5.7 & 0.01 & 5.10 & 0.018 & 1.7 & 0.2 \\
\hline November & 2.8 & 0.09 & 12.2 & 0.0005 & 3.15 & 0.067 & 2.8 & 0.09 \\
\hline January & 11.4 & 0.001 & 9.3 & 0.002 & 5.30 & 0.015 & 9.5 & 0.002 \\
\hline February & 10 & 0.001 & 17.6 & 0.00006 & 2.80 & 0.048 & 9.1 & 0.002 \\
\hline March & 5.6 & 0.01 & 8.6 & 0.002 & 1.50 & 0.25 & 10.2 & 0.1 \\
\hline April & 14.1 & 0.0001 & 12.4 & 0.0004 & 1.82 & 0.19 & 10.2 & 0.001 \\
\hline June & 7.5 & 0.004 & 11 & 0.0007 & 1.43 & 0.265 & 4.4 & 0.03 \\
\hline
\end{tabular}

${ }^{2}$ Results of one-way ANOVA for total bird richness and abundance, abundance without

Yellow-winged Blackbird (Agelaius thilius) and abundance of species associated to open gaps (see Table 1) for three areas with different nutrient levels in the Spartina alterniflora marsh from Bahía Blanca bay, Argentina. For all comparisons degrees of freedom is 2 . 


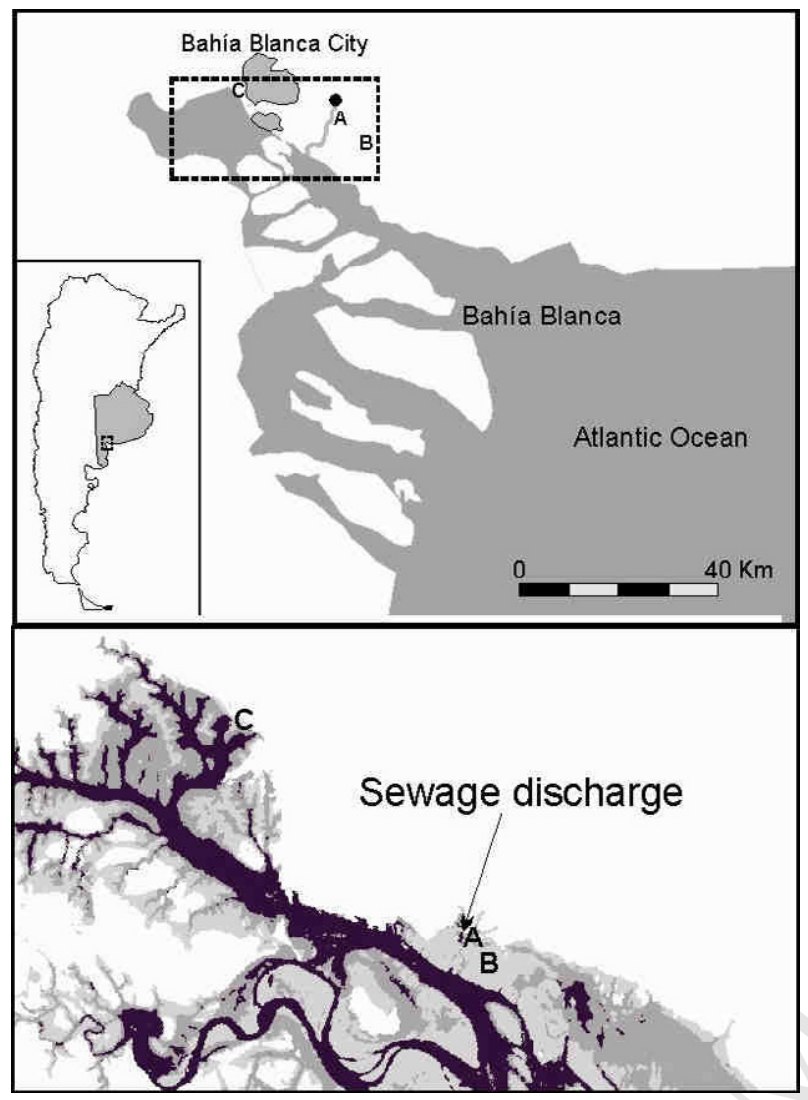



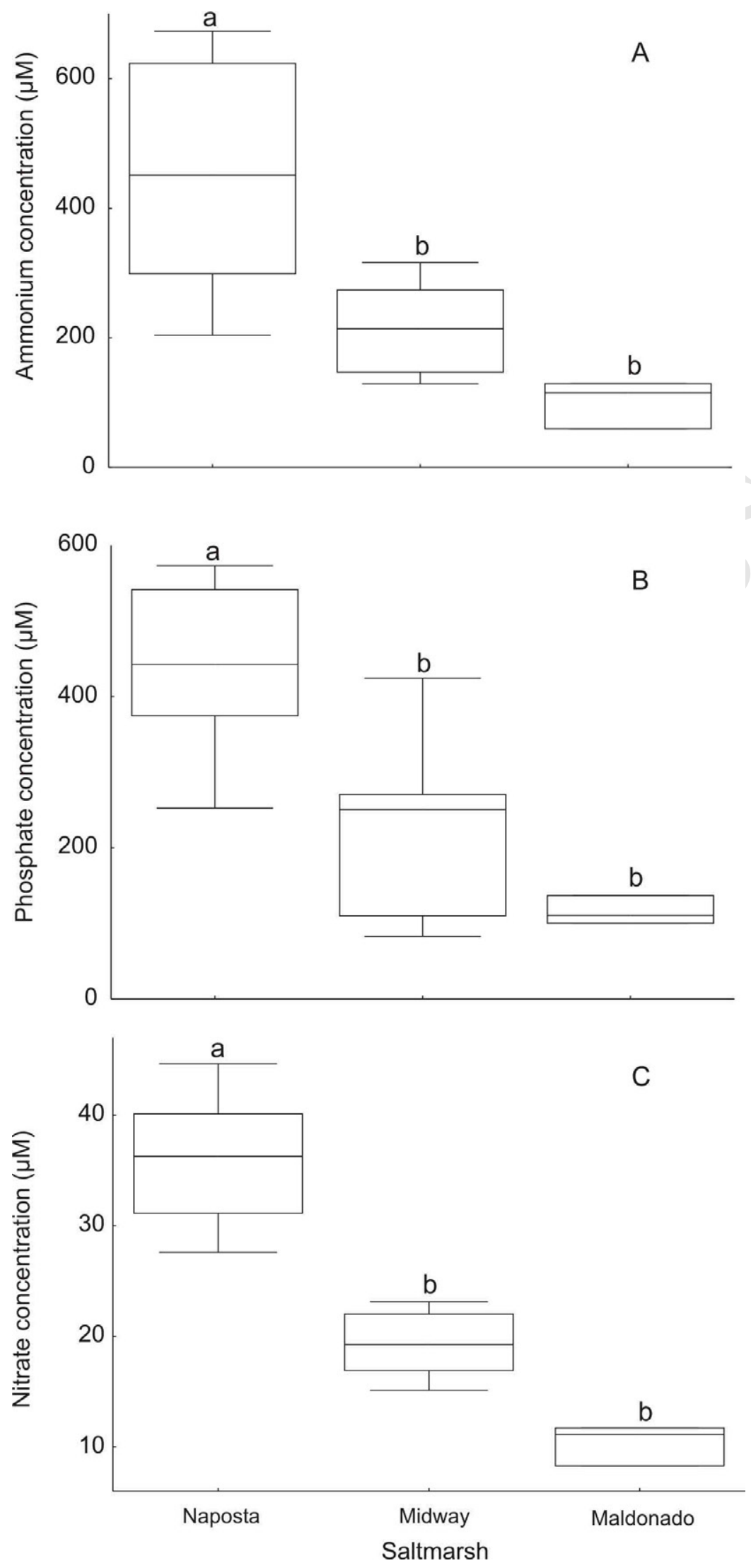


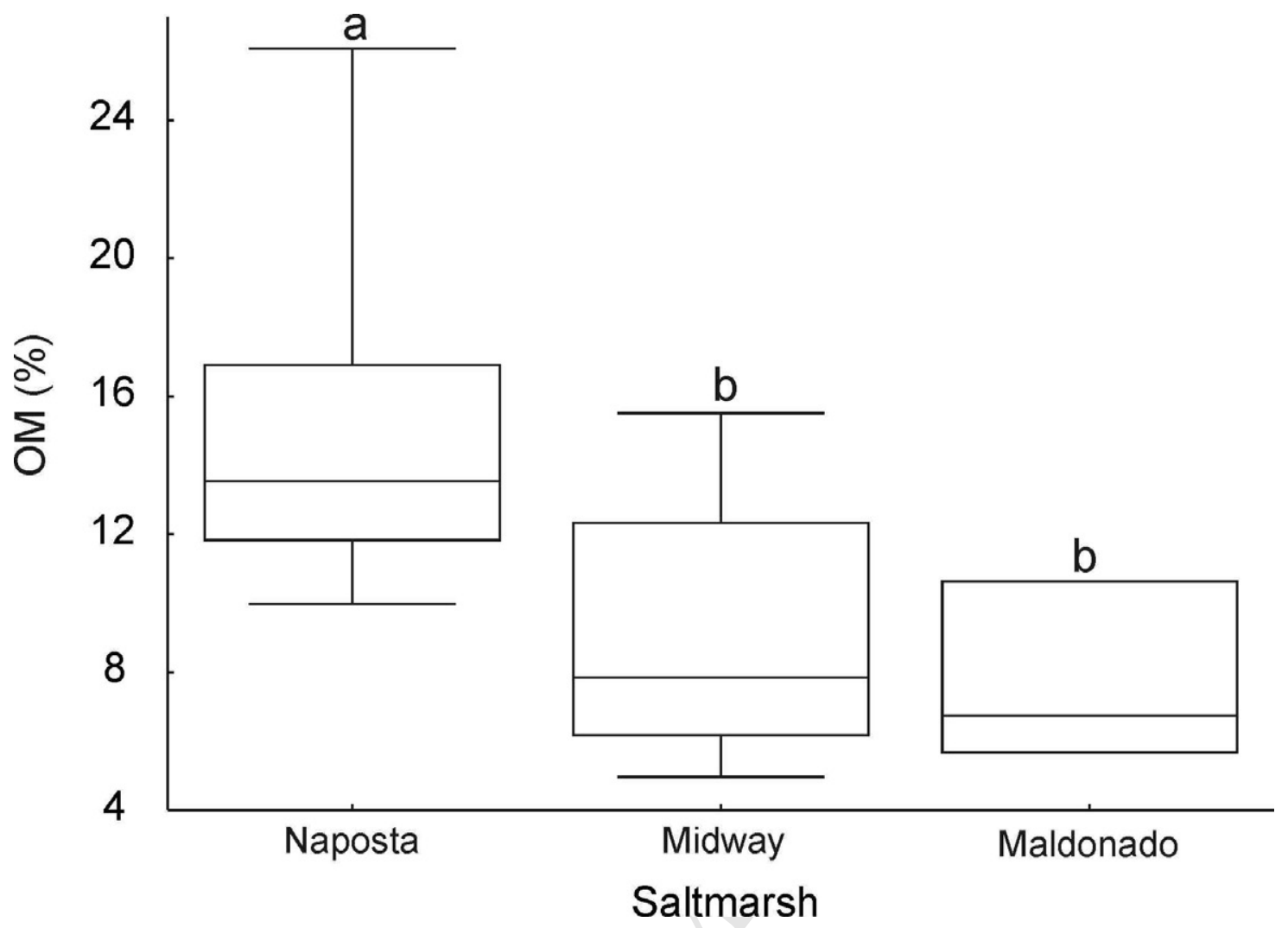



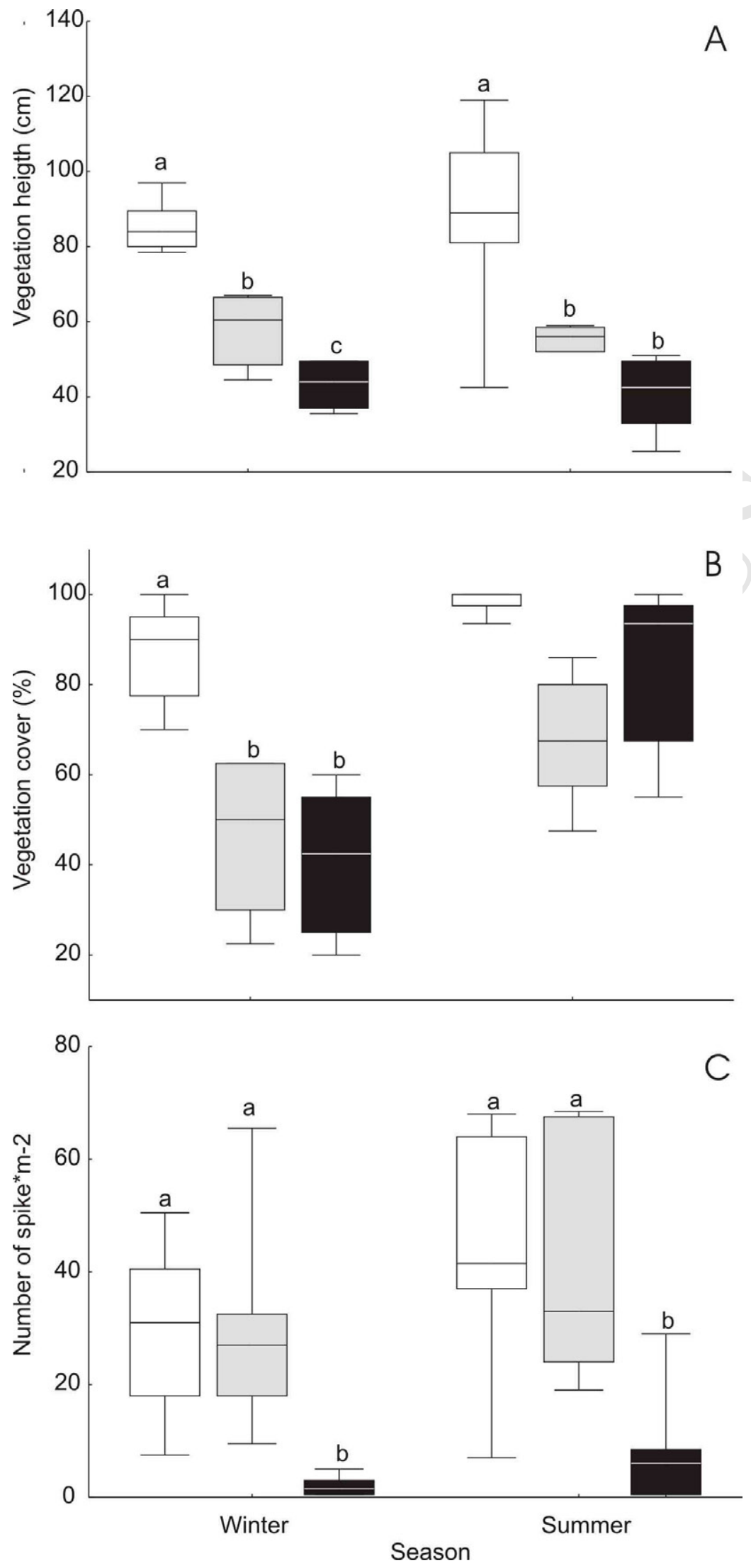

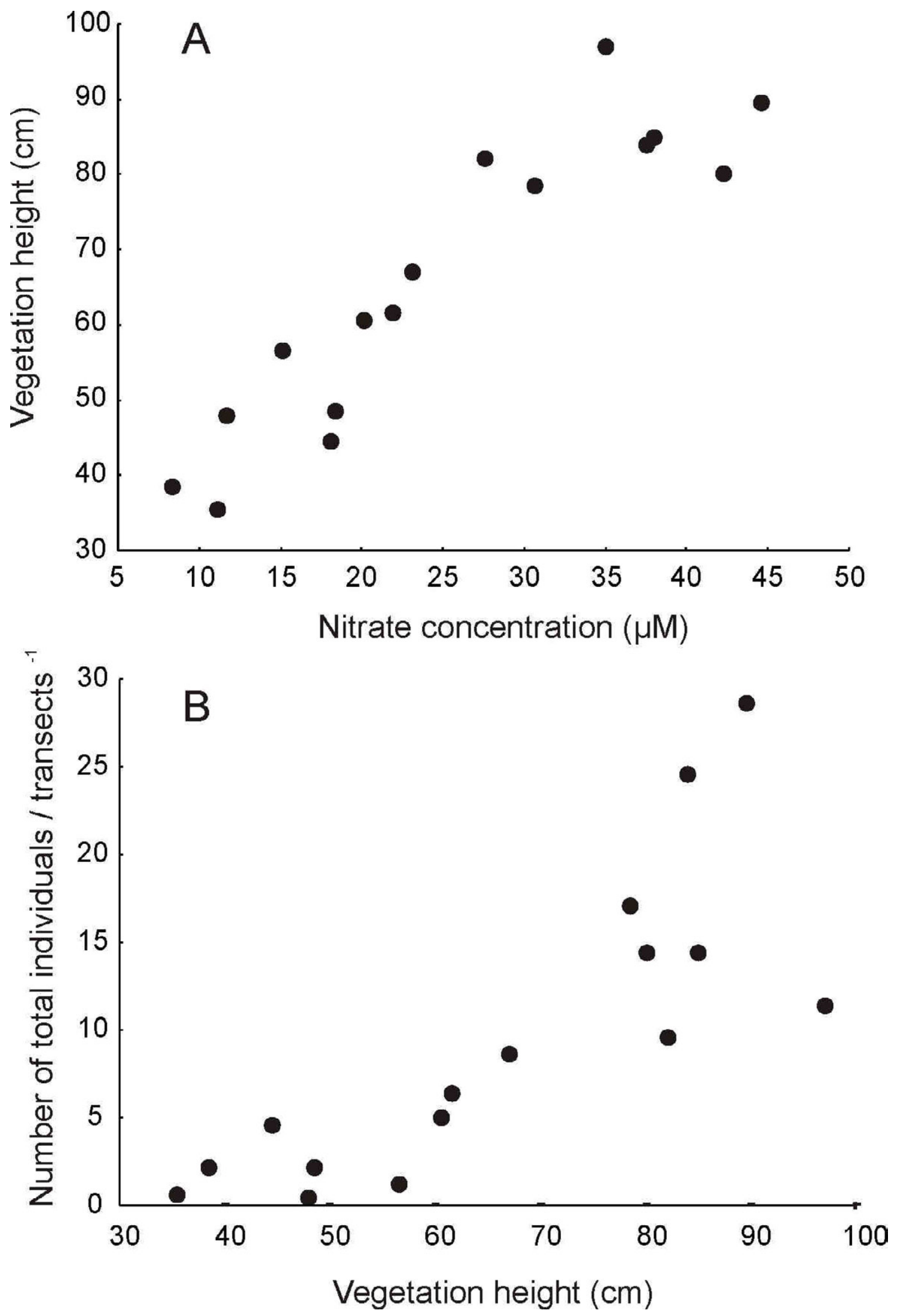

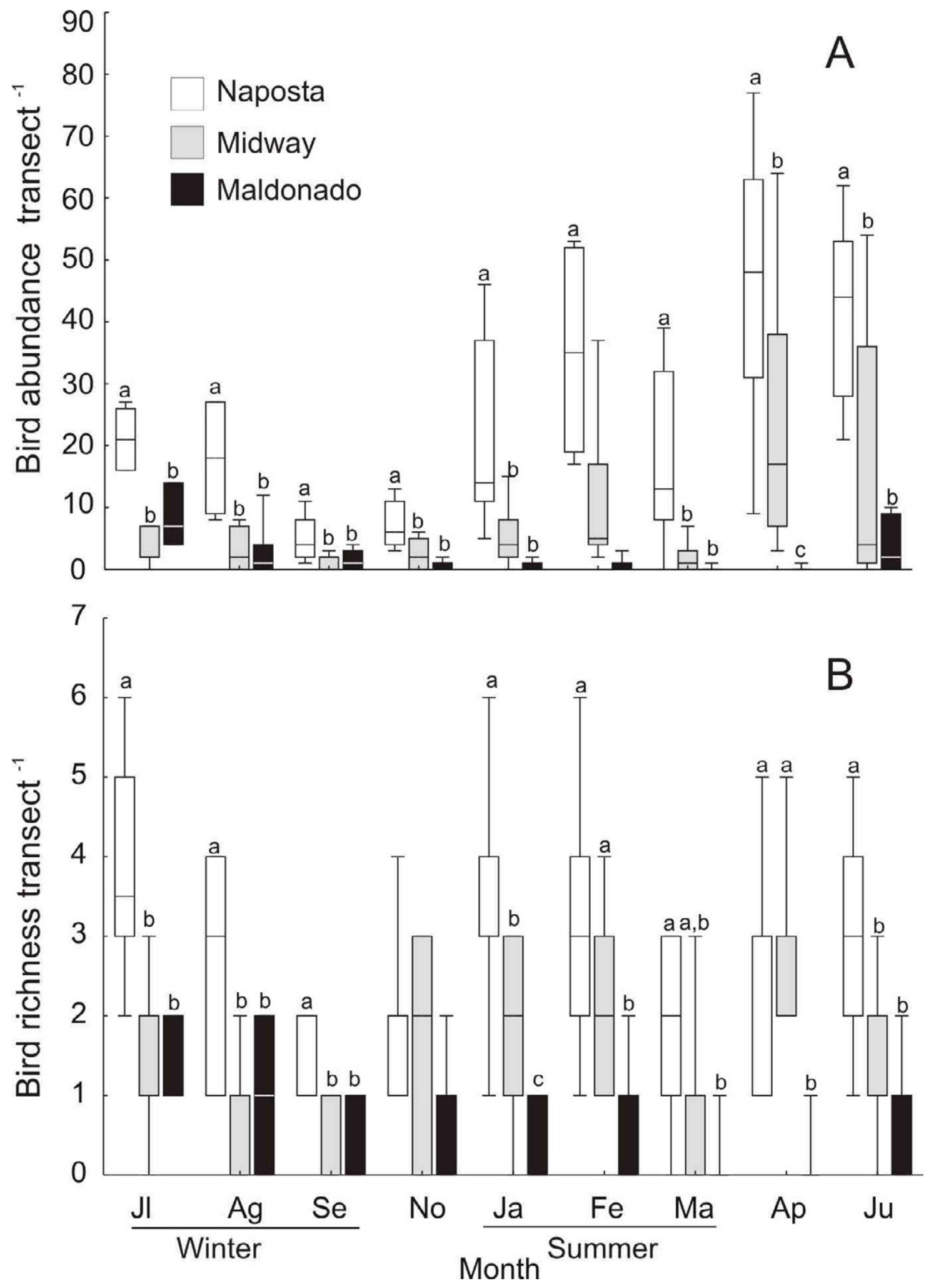